\title{
The 1952 Meru Land Case: A Pan Africanism Mission
}

\author{
Lessie B. Tate, PhD \\ Adjunct Professor \\ Prairie View A \& M University \\ Prairie View, Texas 77446 \\ United States of America \\ Jackson de Carvalho, PhD \\ Associate Professor \\ Prairie View A \& M University \\ Prairie View, Texas 77446 \\ United States of America
}

\begin{abstract}
Black nationalism and Pan-Africanism coalesced through the connection between Africans and members of the African Atlantic diaspora as a result of two World Wars and the black world's outrage at the lack of support from the League of Nations for Ethiopia during the Italo-Ethiopian war. The reunion of Africans with the members of the African diaspora permitted the sharing of a recognized common destiny that Jim Crow, colonialism, and racial subordination held for the black world. At the conclusion of World War II, the arts, literature, education, sports, politics, education, religion, and labor created a newfound interconnectedness among blacks globally. A number of major capital cities in Europe and the United States, where those of the black world engaged in common ventures, provided space for "exceptional liberties of expression" thus escalating the development of black hubs where linkage between the black world were made. It was in such a space in 1947 London that a linkage between African American Alberta Seaton and her West Indian husband, Earle Seaton, and East Africans Thomas Marealle and Peter Koinange, resulted in their 1952 mutual involvement in what came to be known as the Meru Land Case.
\end{abstract}

Keywords: Pan Africanism, black internationalism, black hubs, link, black liberation

\section{Introduction}

The black world recognized the necessity of education as an equalizer in tempering the race's denigrated position in the Western world. It was not an anomaly that education was key to the initial meetings of Tanzanians and African Americans in the black hubs of England and the United States. Education brought Earle Seaton and Alberta Jones Seaton in contact with Tom Marealle and Peter Koinange in London in 1947 This relationship blossomed prior to Tanganyika Territory's independence. The extension of hospitality between Tanzanians and African Americans was manifested in the accommodation by US Pan-Africanist activists to the needs of Tanganyika's anti-colonial movement. A connection of this manner was the binding agent that developed, sustained, and matured the Tanzanian/African American linkage. This article will show how from the late 1940s and into the 1950s black hubs served as nexus for the development of Pan-African link ups and served as a staging ground for the initial international battles against colonialism and racism.

\section{Education in Europe unites the black world}

The lives of Alberta Jones Seaton, Earle Seaton, and Tom Marealle illustrate the fluidity and function of networks of those who are involved in black internationalism ${ }^{1}$ in the 1940s. Alberta Jones was an African American biologist from Houston, Texas. ${ }^{2}$ While at Howard University in Washington, DC, she met Earle Seaton, a student from Bermuda, who also studied biology there from 1942 to 1946. Because of the limited options of African Americans for graduate study during the period, both Jones and Seaton traveled to Europe in the late 1940s to pursue advanced degrees. Jones received her doctorate in biology from the University of Brussels, while Seaton graduated from London University as a barrister in 1948. In this same year, Alberta Jones and Earle Seaton married in London.

\footnotetext{
1 Ibid.

${ }^{2}$ Alberta Seaton, in discussion with the author, February 26, 2002. 
The Seaton's relationship with Marealle and Koinange set the course for their involvement in the anticolonial movements in Tanganyika and Kenya. Earle Seaton attended London University with Thomas Marealle, a Tanzanian from the Kilimanjaro-Meru region. Marealle was a descendent of Marealle of Marangu. During his reign as chief of the Chagga he was said to have participated in a policy of intrigue with the first Germans in the first colonial government of Tanganyika. ${ }^{3}$ One of the methods of German intervention was to pursue alliances with strong chiefs that acknowledged German authority. Marealle's politics of intrigue allowed collaboration with the Germans to advance the Chagga's own interests. ${ }^{4}$ Germans did not understand the intricacies of East African politics and as such were played as pawns against other Chagga rivals. It was also said that his grandfather, Chief Marealle, in 1909 had 15,000 coffee bushes in Marangu, although this is thought to be somewhat of an exaggeration. ${ }^{5}$ It is no surprise that Marealle is the one who solicited Earle Seaton for his assistance while attending the London School of Economics.

Seaton also met Peter Koinange from Kenya while he was doing postgraduate studies at the University of Cambridge's St. John's College and later delivered the Munro lectures designated for international scholars at Edinburgh. ${ }^{6}$ During this period, Koinange was living in Britain and Ghana as a result of being listed by the Kenyan government as subject to detention if he returned home. ${ }^{7}$ Marealle and Koinange were among the first East Africans to gain advanced educations. Peter Koinange's father, Koinange wa Koinange, Chief of the Kikuyu in Kenya, was appointed government chief by the British colonial government. ${ }^{8}$

It was Koinange's father, with Mathew Njoroge, Josiah Njonjo, and Waruhiu Kungu, who formed the Kikuyu Association (KA) in 1919. ${ }^{9}$ The KA's mission was to pressure the British colonial government to return the Kikuyu stolen land that resulted from the land alienation for white settlers in Kenya. ${ }^{10}$ Because of Koinange's outspokenness, the colonial officials dubbed him "the evil genius of Kikuyuland" and retired him from government service in 1948. Losing his position as government chief, the elder Koinange was labeled by the government as a collaborator who rebelled and turned nationalist. Chief Koinange had a short-lived central role in the initiation of the oath-taking campaign in the early phase of the Mau Mau movement. ${ }^{11}$ The Mau Mau rebellion in 1952 was a Kenyan peasant uprising against the colonial state. African Americans followed closely the black press's extensive coverage of the flare up in Kenya. In a 1955 New York Amsterdam editorial, Lester Granger captured how Great Britain had taken skillful advantage of the Mau Mau rebellion "by tying the killer label on all nationalists that protest against seizure of the best of Kenya's precious land for the benefit of a few thousand whites."12

During this era Jomo Kenyatta, leader of the Kenya African Union traveled Kenya preaching the early Pan-Africanism slogan coined in the Atlantic African diaspora in 1920 by Marcus Garvey: "Africa for Africans." ${ }^{\text {"13 }}$ For this the British arrested Kenyatta for his alleged connection to Mau Mau. African Americans took notice, and inspired by the rebellion of their kinsmen, the Seatons and another educated black elite joined in the struggle and took up the symbolic cry of the Mau Mau.

Nationalism was very much a family affair in the Koinange family. Chief Koinange's sons played a significant role in their father's life. Though he remained in Africa, the old chief sent advice to son Peter in London, who was assisting his friend Earle Seaton in preparing for the Meru Land Case. ${ }^{14}$ Alberta Seaton stated that it was the lifetime friendship formed by these "colonial" buddies that influenced Earle Seaton to move to Tanganyika.

${ }^{3}$ G. S. W. Gwassa, "The German Intervention and African Resistance in Tanzania," in A History of Tanzania, ed. I. N.

Kimambo and A. J. Temu (Nairobi: East African Publishing House, 1969), 95.

${ }^{4}$ Ibid.

${ }^{5}$ John Iliffe, "The Age of Improvement and Differentiation (1907-45)" in A History of Tanzania, ed. I. N. Kimambo and A.

J. Temu (Nairobi: East African Publishing House, 1969), 136.

${ }^{6}$ Seaton, discussion with author, February 26, 2002.

7 "British Africa: The First of the Last," Time, February 1, 1960, http://content.time.com /time/subscriber/article/0,33009,826042,00.html.

${ }^{8}$ John Iliffe, A Modern History of Tanganyika (Cambridge, UK: Cambridge University Press, 1979), 501.

${ }^{9}$ Wunyabari O. Maloba, Mauand Kenya: An Analysis of a Peasant Revolt (Bloomington: Indiana University Press, 1998$), 46$.

${ }^{10}$ Ibid.

${ }^{11}$ Ibid, 60.

${ }^{12}$ Lester B. Granger, "Manhattan and Beyond," New York Amsterdam News, April 16, 1955, 16.

${ }^{13}$ James R. Lawson, "Nations Notes," Atlanta Daily World, September 9, 1952, 2.

${ }^{14}$ Anton Nelson, The Freemen of Meru (New York: Oxford University Press, 1967), 43. 
Alberta Seaton explained that her reference to the "colonials" was a term her husband and his friends called themselves as subjects of the British metropole, who dedicated their lives to anticolonialist efforts. ${ }^{15}$ Marealle convinced Earle Seaton that Tanganyika was in desperate need of his help, and Seaton left London immediately after graduating, arriving in East Africa in August of 1948. The Tanganyikan government required six months residency before Seaton could practice law. Seaton's first law office was in Moshi, Tanganyika, and he later opened offices in Kenya and Uganda.

Upon completion of her degree in 1949, Alberta Seaton joined her husband in East Africa. Expecting their first child at the time, she did not travel directly to Moshi upon arriving in East Africa but remained in Nairobi with Chief Koinange's senior wife until the birth of their daughter. It is this hospitality between people of Africa and the diaspora that made it possible for Alberta Seaton to be with her husband in the midst of his anticolonial activities in East Africa.

\section{The Meru Land Case and the rise of nationalism}

Tanganyika was a United Nations Trusteeship territory when the Seatons settled in East Africa. The couple settled near Marealle's home in the Kilimanjaro-Meru region. During the period between 1938 and 1948, increased European immigration in the area caused mounting pressure from the new settlers in East Africa for more land. The negative results for Marealle's people, the Wachagga in Tanganyika, and Koinange's people, the Kikuyu in Kenya, was massive alienation from their own land. ${ }^{16}$ The 1951 eviction of residents of two Meru farms, the Engare Nanyuki and Leguruki, by colonial officials for the creation of a homogenous block of European landholdings between Meru and Kilimanjaro evoked an uproar in the region. ${ }^{17}$ Ironically this was the Wameruhomeland that had been repurchased from Europeans between the World Wars. ${ }^{18}$ A Chagga alliance, which included Meru leaders, the Kilimanjaro Union, and Kenyan politicians, was formed to formally address the issue. In a petition sent to the United Nations on June 9, 1952, Meru leaders formally requested to be present at the reading of the complaint. At the filing of the petition, Marealle was the Chagga Paramount Chief. ${ }^{19}$ Clearly this event had been foreseen by Marealle during his period of education in London, which led him to seek Seaton's assistance. Kirilo Japhet, Secretary of the Arusha Branch of the Tanganyika African Association (TAA), and Seaton, then practicing law in Moshi, were chosen as representatives to appear before the Trusteeship Council on June 30 and July 21, 1952. ${ }^{20}$

There was a four-month wait between Japhet's and Seaton's first appearance before the United Nations Trusteeship Council and the meetings of the East African Section of the Colonial Office in London. ${ }^{21}$ The opinion rendered from the colonial officials' meeting with Japhet and Seaton was that the displacement of the Wameru was caused by "theirill-advised refusal to accept the compensation offered by the Administering Authority." ${ }^{22}$ Seaton returned to Tanganyika; Japhet remained in the United Kingdom, where he was interviewed by the press and Members of Parliament in an attempt to elicit support for the Wameru's cause from Lord Fenner Brockway, a member of the Labour Party in the House of Commons and known during the 1950s as the "MP of Africa.",23

While in London, Japhet met with Nyerere, who was on holiday from his studies at Edinburgh University. ${ }^{24}$ Japhet's East African council was not limited to Nyerere, for he received encouragement and advice from officials of the Kenya African Union (KAU) in the United Kingdom, including Peter Koinange, Fred Kubai, and Dr. Munyua Waiyaki. This is evidence of the unity formed through regional Pan Africanism in East Africa.

Later that year, Fred Kubai was arrested in October 1952 with Jomo Kenyatta and four others; they were to become known as the six shujaasKapenguria - the six heroes of the Kapenguria-who were tried for treason in the small town of Kapenguria in northwest Kenya. Kubai was released in 1961, becoming a member of parliament for Nkuru east at Kenya's independence, and forever revered as a founding father of a free Kenya. Koinange went on to serve as Kiambaa Member of Parliament from 1963 to 1974, and Waiyaki would serve as Foreign Minister of Kenya from 1974 to 1979.

${ }^{15}$ Seaton, discussion with author, February 26, 2002.

${ }^{16}$ Iliffe, A Modern History of Tanganyika, 450-451.

${ }^{17}$ Iliffe, A Modern History of Tanganyika, 451.

18 Ibid.

${ }^{19}$ Ibid.

${ }^{20}$ Seaton, discussion with author, February 26, 2002; Nelson, Freemen of Men, 53.

${ }^{21}$ Kirilo Japhet and Earle Seaton, The Meru Land Case (Nairobi: East African Publishing House, 1967), 46; Nelson, Freemen of Meru, 66.

22 Japhet and Seaton, Meru Land Case, 46.

${ }^{23}$ Japhet and Seaton, Meru Land Case, 46; Nelson, Freeman of Meru, 66.

24 Ibid. 
The Ugandan nationalist leader Semakula Mulumba was also in London as spokesman for the Bataka Federation during this time. ${ }^{25}$ In Japhet's meeting with Nyerere in London prior to traveling on to New York for the Meru Land Case hearings, the task at hand that awaited him upon his return to Tanganyika was made clear. ${ }^{26}$ After Japhet's return to East Africa in 1953, he toured Tanganyika under the auspices of TAA. ${ }^{27}$ At these meetings he not only detailed the complaints of the Wameru that had taken him and Seaton to the United Nations, but he also raised the subject of independence for this territory as the solution for these and other injustices. ${ }^{28}$

News of Tanganyika's first venture towards liberation was not only spread throughout Tanganyika upon Japhet's return, but as well in the United States after the Meru Land Case, and this news was not lost to the US black community. Jet, the most widely read African American weekly news magazine, published reports of the event in their foreign news segment. The magazine reported on the case of 3,000 Africans, who had been evicted to the benefit of 13 white settlers in Tanganyika, and their formal appeal to the United Nations, noting that Ralph Bunche was the trusteeship committee's head. ${ }^{29}$

In 1951 Jet's circulation was estimated at 300,000 readers. James Meriwether found that the black press reached much farther than its circulations indicated. ${ }^{30}$ Newspapers and magazines from the black press were passed from family to family and were found and discussed in community locales such as barbershops, beauty shops, churches, and lodges. ${ }^{31}$ The black press served as a medium for black intellectuals to communicate with each other while serving as a tool for spreading ideas from the African American elite to the broader black community. This allowed the African American community at large in the 1950 s and 1960 s to follow all of Africa in its quest for liberation and in many ways made them a part of the struggle.

The Japhet advice received from East African nationalists in Europe prior to his appearance at the United Nations is a prelude to the practice in East Africa of Pan-Africanism that propels those in leadership positions to work together in anti-colonialism movements. Koinange, Kubai, Nyerere, Waiyaki, and Mulumba are each members of their respective country's newly forming nationalist movements. The Meru Land Case represents an important collaborative political initiative that drew an emotional response from Africans and effectively increased feelings of nationalism among the masses within East Africa. ${ }^{32}$ Under British guidance the colonial governments of Tanganyika, Kenya, and Ugandainitially known as the East African Community after World War II-reflected a British attempt to secure their position in a collective initiative to stamp this region's identity upon the conscience of the modern world. ${ }^{33}$ It created a unified identity that distinguished the East African population in its new position of independence and signalled a complete and confident transition from the colonial era. ${ }^{34}$ Uganda's Minister of State, Grace Ibingira, proclaimed in 1957, "rather than divide us ... the British have united us!"35

During the three days of September 16, 17, and 18 in 1958, countrymen from these three East African nations were joined by nationalists from Zanzibar and Nyasaland to formally organize the Pan-African Freedom Movement for East and Central Africa (PAFMECA) at its founding conference in Mwanza, Tanganyika. ${ }^{36}$ Although short lived, PAFMECA functioned as a leader's forum, which served more as a symbol than an organization for the moral and psychological support of East African nationalists. ${ }^{37}$

25 Ibid.

${ }^{26}$ Iliffe, A Modern History of Tanganyika, 503.

${ }^{27}$ Lionel R. Cliffle, "Nationalism and the Reaction to Enforced Agricultural Change in Tanganyika during the Colonial Period," Taamuli 1 (1972): 7.

28 Ibid.

29 “3000 Africans Evicted for 13 White Settlers,” Jet, December 11, 1952, 14, http://booksgoogle.com/books/about/Jet.htm1.

${ }^{30}$ James H. Meriwether, Proudly We Can Be Africans: Black Americans and Africa, 1935-1961 (Chapel Hill: The University of North Carolina Press, 2002), 8.

${ }^{31}$ Gunnar Myrdal, An American Dilemma: The Negro Problem and Modern Democracy. 1944. Reprint (New Brunswick, NJ: Transaction Publishers, 1996), 909.

${ }^{32}$ Carole Boyce Davies, ed., Encyclopedia of the African Diaspora: Origins, Experiences and Cultures (Santa Barbara, CA: ABC-CLIO, 2008), 408.

${ }^{33}$ Ibid, 407.

34 Ibid.

${ }^{35}$ Joseph S. Nye Jr., Pan-Africanism and East African Integration (Cambridge, MA: Harvard University Press, 1967$), 35$.

36 "Pan-African Freedom Movement of East and Central Africa" International Organization 16, no. 2 (1962), doi:10.1017/S000208183000122x.

${ }^{37}$ Nye, Pan-Africanism, 122-124. 
Japhet's council, with members of the East African community in Europe during his visit, demonstrated the early cohesiveness for liberation established with East African regional nationalists and their practice of Pan-Africanism to achieve strength from what Koinange, then PAFMECA's secretary, declared was "unity."38

East Africa's political unity was applauded and closely watched not only throughout Africa, but by blacks in America as well. In an article titled "Pan African Freedom Movement," the Chicago Defender reported Nyerere's belief that Kenya, Uganda, Tanganyika, Zanzibar, and possibly Nyasaland should reach independence and join the Federation at the same time. ${ }^{39}$ Nyerere even expressed in this interview his willingness to hold back Tanganyika's advance while the others caught up. ${ }^{40}$

Although the Wameru were not successful in regaining the two lost farms, the effort was critical in awakening the anticolonialist movement in Tanganyika. A. J. Temu stated that "if any single factor helped to stir the African masses in Tanzania [into] political action and ... pave the way for TAA and later for Tanzania African National Union and [interaction with black leaders on the international political stage], it was the Meru Land Case."41

\section{Conclusion: Black hands across the sea: Alberta and Earle Seaton}

Ebony's March 1972 article, "Black Hands across the Sea," examined Earle Seaton's continued influence in transatlantic black society. ${ }^{42}$ African American entrepreneur Thomas A. Woods was founder and owner of TAW, an international leasing firm that leased heavy equipment to developing countries in Africa. ${ }^{43}$ Woods, while attending Columbia, met Earle Seaton when Seaton was at Howard. ${ }^{44}$ Seaton stayed in contact with Woods and other American friends while he was in Tanzania. Woods states that it was Seaton who influenced him to establish his international business. ${ }^{45}$ The growth of such a Tanzanian/African American linkage stemmed from the US Pan-Africanists' recruitment of individuals within their established networks.

As the 1972 article in Ebony showed, Seaton remained well entrenched in the human rights network. After the Meru Land Case and the birth of his second child, Seaton returned his family to the United States in 1953. Driven to advance his involvement in the African freedom movements and development of newly independent African nations, Seaton began his doctoral studies in international affairs at the University of Southern California in 1956. Once Seaton completed his dissertation in 1961, he returned to Tanganyika to work in the Ministry of Foreign Affairs until 1964. Seaton's ability to relocate with ease was a great asset to the Tanganyikan cause, as his residency in the United States from 1953 until the 1961 independence of Tanganyika was beneficial in setting the course for the success of the early visits of Nyerere to the United Nations in New York. After leaving his post in the Tanganyikan Ministry of Foreign Affairs, Seaton served as a judge in Arusha from 1965 to 1969 and then on Tanzania's Legal Counsel to the United Nations from 1969 to 1971.

In the meantime, Alberta Seaton, who had attained her Ph.D. prior to her marriage, was pursuing an academic career. She periodically taught at Makerere University in Uganda and at Texas Southern University in her hometown of Houston. In addition to traveling with her husband from time to time, she managed their homes in Tanzania and Houston. ${ }^{46}$

\section{References}

Diawara, Mathia. In Search of Africa. Cambridge: Harvard University Press, 1998.

Edward, Brent Haynes. The Practice of Diaspora: Literature, Translation, and the Rise of Black Internationalism. Cambridge: Harvard University Press, 2003.

Gilroy, Paul. The Black Atlantic: Modernity and Double Consciousness. Cambridge: Harvard University Press, 1993. Gomez, Michael. Reversing Sail: A History of the African Diaspora. New York: Cambridge University Press, 2005. Japhet, Kirilo and Earle Seaton.The Meru Land Case. Nairobi: East African Publishing House, 1967.

${ }_{39}^{38}$ Nye, Pan-Africanism, 35.

39 "Pan-African Freedom Movement," Chicago Daily Defender, November 12, 1960, 10.

${ }^{40}$ Ibid.

${ }^{41}$ A. J. Temu, "The Rise and Triumph of Nationalism," in A History of Tanzania, ed. I. N. Kimambo and A. J. Temu (Nairobi: East African Publishing House, 1969), 205.

42 "Black Hands across the Sea" Ebony, March 1972, 89, http://ebony.com /Archive.aspx.

${ }^{43}$ Ibid.

${ }^{44}$ Ibid.

${ }^{45}$ Ibid.

${ }^{46}$ Alberta Seaton, fact sheet. 
Kimambo, I. N. and A. J. Temu, ed. A History of Tanzania. Nairobi: East African Publishing House, 1969.

Masolo, D. A. African Philosophy in Search of Identity. Bloomington: Indiana University Press, 1994.

Maloba, Wunyabari O.Mau Mau and Kenya: An Analysis of a Peasant Revolt. Bloomington: Indiana University Press, 1998.

Meriwether, James H. Proudly We Can Be Africans: Black Americans and Africa, 1935-1961.Chapel Hill: The University of North Carolina Press, 2002.

Myrdal, Gunnar.An American Dilemma: The Negro Problem and Modern Democracy. 1944 Reprint. New Brunswick, NJ: Transaction Publishers, 1996.

Nelson, Anton.The Freemen of Meru. NewYork: Oxford University Press, 1967.

Nye Jr., Joseph S. Pan-Africanism and East African Integration. Cambridge, MA: Harvard University Press, 1967.

Walters, Ron. Pan Africanism in the African Diaspora: An Analysis of Modern Afrocentric Political Movement. Detroit: Wayne State University, 1993.

Williams, Raymond. The Politics of Modernism: Against the New Conformists. London: Verso, 1989. 